\title{
Localized lichen myxedematosus
}

INSERM

\section{Source}

INSERM. (1999). Orphanet: an online rare disease and orphan drug data base. Localized lichen myxedematosus. ORPHA:86795

Localized lichen myxedematosus is a group of skin diseases characterized by the development of papules, nodules and/or plaques with mucin deposits and a variable degree of fibrosis in the absence of thyroid disease. The group comprises five subforms: nodular lichen myxedematosus, discrete papular lichen myxedematosus, papular mucinosis of infancy, acral persistent papular mucinosis and self-healing papular mucinosis. 